\title{
Perceived Risk, Perceived Technology, Online Trust for the Online Purchase Intention in Malaysia
}

\author{
Kwek Choon Ling (Corresponding author) \\ Faculty of Management and Information Technology, UCSI University \\ 1, Jalan Menara Gading, UCSI Heights, 56000 Kuala Lumpur, Malaysia \\ Tel: 60-16-688-6248 E-mail:kwekcl@ucsi.edu.my \\ Dazmin bin Daud \\ Faculty of Management and Information Technology, UCSI University \\ 1, Jalan Menara Gading, UCSI Heights, 56000 Kuala Lumpur, Malaysia \\ Tel: 60-12-290-2513Ｅ-mail: dazmindaud@ucsi.edu.my
}

Tan Hoi Piew

Faculty of Accountancy and Management, Universiti Tunku Abdul Rahman

Lot PT21144, Jalan Sungai Long, Bandar Sungai Long, Cheras, 43000 Kajang, Selangor, Malaysia

Tel: 60-16-286-2719 E-mail: hptan@utar.edu.my

\author{
Kay Hooi Keoy \\ Centre of Excellence for Research, Value Innovation and Entrepreneurship (CERVIE) \\ UCSI University, 1, Jalan Menara Gading, UCSI Heights, 56000 Kuala Lumpur, Malaysia \\ Tel: 60-3-9101-8880-3355 E-mail: keoykh@ucsi.edu.my \\ Padzil Hassan \\ Centre of Construction Project \& Infrastructure Management (CPIM) \\ Faculty of Architecture, Planning and Surveying \\ Universiti Teknologi MARA, 40450 Shah Alam, Selangor Darul Ehsan, Malaysia \\ Tel: 60-3-5521-1670Ｅ-mail: padzil037@salam.uitm.edu.my
}

Received: November 26, 2010 Accepted: December 28, 2010 doi:10.5539/ijbm.v6n6p167

\begin{abstract}
The past decades have witnessed the beginning of a major directional change of consumer behaviour, from physical stores purchasing behaviour to online purchasing behaviour in the retailing industry, especially the youngsters in Malaysia. Therefore, the aim of this research is to evaluate and validate the impacts of perceived technology and perceived risk on the online trust and how online trust is related to online purchase intention. This study also investigates the impact of online trust in mediating the relationship between perceived technology and online purchase intention. A total of 250 sets of questionnaire were distributed to the full time undergraduate information technology students in a private university that is located in Kuala Lumpur. The findings revealed that perceived technology and perceived risk are positively related to the online trust; online trust is positively related to online purchase intention and perceived technology is positively related to the online purchase intention. In addition, the finding also concluded that perceived technology is positively related to online purchase intention, mediated by online trust.
\end{abstract}


Keywords: Perceived technology, Perceived trust, Online trust, Online purchase intention

\section{Introduction}

The past decades have witnessed the beginning of a major directional change of consumer behaviour, from physical stores purchasing behaviour to online purchasing behaviour in the retailing industry. In Malaysia, the introduction of the first Internet Service Provider (ISP) JARING was back in 1992, and later, TM Net in 1995 changed the consumer shopping behaviour from traditional purchasing to online purchasing (Chua, Khatibi, and Hish, 2006). In a survey conducted by Malaysia Communication and Multimedia Commission (MCMC, 2008), the number of broadband subscribers in Malaysia has increased from 7,843,000 users in 2007 (Quarter 1) to 10,708,000 users in 2008 (Quarter 1). This growth indicates a $36.53 \%$ increase in broadband subscribers. According to Ninth Malaysian Plan - Chapter 9 (Malaysia Prime Minister Department, n.d.), the sale of goods and services over the internet or e-commerce had grown significantly, yielding an average annual rate of $81.8 \%$ (RM 11.1 billion in 2003 to RM 36.7 billion in 2005). This implies that the rapid growth of internet usage and subscriptions in Malaysia had contributed to the high number of total sales. Accordingly, Dann and Dann (2001) argue that the proliferation of the consumer online shopping phenomenon is due to the ease of information accessibility online, thus, consumers are becoming more knowledgeable and more efficient by shopping online.

Shelly, Cashman and Vermaat (2007) find that most of the consumers conduct their shopping, investing, and banking activities via internet. These activities are executed through dedicated websites where users visit an online store front and then make purchases for flight tickets, hotel rooms, travel packages, clothes, cosmetics and electronic goods over the web. Chen and Barnes (2007) argue that the reasons why people do not purchase goods and services via internet are related to online security and privacy, reliabilities of companies and website technology. Trust in an online website is an important determinant in determining the success or failure of any e-commerce activities in the marketplace (Koufaris and Hampton-Sosa, 2004). Kaur (2005) also states that customers who involve in doing online purchase are concerned about unsafe products, insecure payment methods, loss of personal privacy, and misuse of personal information. In consideration to the diversity of the current research in extant literature, this research is conducted to study the determinants of online trust (i.e., perceived risk and perceived technology), the antecedent relationship between online trust and online purchase intention, the antecedent relationship between perceived technology and online purchase intention, and the impact of online trust in mediating the relationship of perceived technology on online purchase intention among tertiary students in a selected private university.

\section{Literature Review}

\subsection{Online Purchasing Behaviour}

According to Pavlou (2003), online purchase intention can be defined as a situation where a consumer is willing and intends to make online transactions. Purchase intention can also be defined as a consumer's intention to build an online relationship and have transactions with a Web retailer (Zwass, 1998). Online transactions are consisted of three steps which are information retrieval, information transfer and product purchase (Pavlou, 2003). The following literature attempts to explore the relationships among perceived risk, perceived technology, online trust and online purchase intention.

\subsection{Online Trust}

Mayer, Davis and Shoorman (1995, p.712) define trust as a tendency of one party that is willing to accept the actions by the other party even though the first party is not being protected by the second party and fail to control the actions of the second party. Rousseau, Sitkin, Burt, and Camerer (1998) state that trust is a psychological state which relies on positive expectations of intentions of a person to the other. According to Rempel, Holmes, and Zanna (1985), when a person trusts the other party, feelings of confidence and security arises within the person towards the other. Moorman, Zaltman and Deshpande (1992) argue that when a person trusts another person, the person is confident and willing to have faith in the other partner that is involved in the exchange process. Trust also occurs when there is a belief that the first party will not take advantage of the second party in any situation even if there are opportunities to do so by the first party (Gefen, 2002b; Hosmer, 1995; Moorman et al., 1992).

In an online transaction, there is no physical interaction between the buyer and the seller, and the payment method is usually paid by credit card, thereby increases the probability that the consumer's financial data may be exposed and used incorrectly. There is also the risk that the product received is not the product that was originally ordered (Flavian and Guinaliu, 2006; Monsuwe, Dellaert, and Ruyter, 2004). Thus, the online transaction can create a sense of powerlessness among online shoppers (Monsuwe, et al., 2004). In these 
uncertain circumstances, the role of online trust comes into play to reduce specific problems of risk that may be encountered by online shoppers (Luhmann, cited in Kim, Ferrin and Rao, 2008).

Some scholars argue that it is easier to convince its customers to stay with the company if the customers have higher degree of trust to the company (Jarvenpaa and Tractinsky, 1999; Yoon, 2002; Balasubramanian, Kanona, and Meron, 2003; Grabner-Krauter and Kaluscha, 2003; Gefen and Straub, 2004). Most of the time, consumers will tend to make judgments about a web store based on the degree of trust that will positively influence consumer's behaviour (Wang, 2003). Lack of trust has become one of the most frequently cited reasons why consumers do not engage in e-commerce (Lee and Turban, 2001). There is also the argument that consumers who do not trust the seller will refuse to involve themselves in the online transactions (Jarvenpaa and Tractinsky, 1999; Urban, Sultan and Qualls, 2000; Gefen, 2002a So and Sculli, 2000; Hedelin and Allwood, 2002; Kim et al., 2008). Therefore, online trust is a very important factor in determining the success of an online website (McKnight and Chervany, 2001; Balasubramanian et al., 2003; Grabner-Krauter and Kaluscha, 2003; Koufaris and Hampton-Sosa, 2004).

When a consumer has a higher degree of trust to the seller, the consumer will elicit higher degree of purchase intentions (Jarvenpaa and Tractinsky, 1999 and Gefen and Straub, 2004). Chen and Barnes (2007) and Gefen (2000a) found that trust is an important factor in influencing purchase intention. The concluding positive relationship between online trust and consumer purchase intentions also supported by other scholars (Yoon, 2002; Balasubramanian et al., 2003; Grabner-Krauter and Kaluscha, 2003; Pavlou, 2003; Gefen and Straub, 2004). In this connection, a hypothesized positive relationship between online trust and online purchase intention (H1) will be tested in this research.

\subsection{Perceived Risk}

Perceived risk is an uncertainty phenomenon encountered by the customers in the purchasing process due to their wrong or unsuitable decisions resulted from their subjective assessments in the decision making process (Murphy and Enis, 1986). According to Kim, et. al. (2007), consumers' perceived risk can also be defined as a consumer's belief about potential uncertain negative outcomes from the E-transaction. Based on the theory of consumers' perceived risk, consumers perceive risk as they face uncertainty and undesirable consequences due to unsuitable decision (Taylor, 1974).

The concept of perceived risk can be classified into various types of risk in the marketing literature (Zikmund and Scott, 1973; Peter and Ryan, 1976). In the online retailing environment, two types of the risk are said to be predominant: security risk and privacy risk (Chen and Barnes, 2007; Murkherjee and Nath, 2007). Security is one of the factors that affect customer trust in online retailing and the security provided by an online retailer refers to the safety of the computer and credit card or financial information (Bart, Shankar, Sultan and Urban, 2005). Perceived privacy is defined as the consumers' ability to control the dissemination of information provided during the online transactions and the ability to control the presence of other people in the environment during the online transaction (Goodwin, 1991).

The level of perceived risk can be reduced by the association with transaction processes (Pavlou, 2003; Koufaris and Hampton-Sosa, 2004). Perceptions of risk in the online marketplace can be reduced by online trust because perceived risk is a strong trust antecedent (Gefen and Pavlou, 2006; Mukherjee and Nath, 2007; Park and Jun, 2003). Chen and Barnes (2007) describe that perceived risk is positively related to initial trust in electronic commerce. Mukherjee and Nath (2007) argue that there is a positive relationship between perceived risk (perceived security and perceived privacy) and trust in online retailing. According to Warrington, Abgrab and Caldwell (2000), by decreasing perceived environmental risks or by raising security of web sites, consumers' online trust is increased. In terms of perceived privacy, when reliability and credibility are recognized, consumers may disclose their private information to web sites and subsequently this can also further reduce consumers' concerns of privacy and security and helps to build online trust toward the web sites (Culnan and Armstrong, 1999).

However, some scholars do not support the above arguments. Kim et al. (2007) argue that trust negatively affects a consumer's perceived risk in the online transaction. The Kim's finding was not supported by Morgan and Hunt. Morgan and Hunt (1994) assert that consumer's perceived risk is not related to trust. Besides, other scholars argue that consumer's perceived risk in the online marketplace can be reduced by trust or by raising security of web sites; it could increase consumer's trust (Pavlou, 2003; Koufaris and Hampton-Sosa, 2004; Warrington, et al., 2000; Culnan and Armstrong, 1999). In conclusion, there is no consensus in the extant literature in determining the relationship between perceived risk and online trust. Therefore, a hypothesized positive relationship between perceived risk and online trust (H2) will be tested in this research. 


\subsection{Perceived Technology}

Gefen, Karahanna and Straub (2003) argue that the components of perceived technology are derived from Technology Acceptance Model (TAM). The perceived technology variable that is actually derived from the Technology Acceptance Model (TAM) suggests that perceived usefulness and perceived ease of use are the two main components of the TAM (Gefen et al., 2003; Koufaris and Hampton-Sosa, 2004; Chen and Barnes, 2007). The perceived ease of use and perceived usefulness of a web site are variables which explain the elements in the development of trust in online shopping (Gefen et al., 2003; Koufaris and Hampton-Sosa, 2004). Therefore, Davis et al. (cited in Chen and Barnes, 2007) argue that TAM could partly explain the elements that affecting consumers' online trust.

The perceived ease of use is defined as the degree to which a person believes that using a particular system would be free of effort (Davis, 1989; Doll, Hendrickson and Deng, 1998; Henderson and Divett, 2003; Erikson, Kerem and Nilsson, 2004; Lee, Fiore and Kim, 2006; McKechnie, Winklhofer and Ennew, 2006). Perceived ease of use is also defined as an indicator of the cognitive effort needed to learn and to utilize new Information Technology (Gefen, 2000). On the other side, Koufaris and Hampton-Sosa (2004) define the perceived ease of use as the subjective perception by the customer regarding the amount of effort necessary to learn and use the website.

Perceived usefulness is defined as the degree to which an individual believes that using a particular system would enhance his or her job performance (Davis, 1989; Lee, et al., 2006, Erikson, et al., 2004; Henderson and Divett, 2003; McKechnie et al. 2006, Doll et al., 1998). According to Gefen et al. (2003), perceived usefulness is a measure of the individual's subjective assessment of the utility offered by the new information technology in a specific task-related context. It is also a subjective perception by the customer regarding the site's utility in his or her shopping task (Koufaris and Hampton-Sosa, 2004).

In the extant literature, there are some scholars who conclude that the perceived technology (perceived ease of use and perceived usefulness) partly influences the online purchase intention (Gefen et al., 2003; Kamarulzaman, 2007; Ha and Stoel, 2008). In a study conducted by Koufaris and Hampton-Sosa (2004), customers are most likely to trust the company when they browse the company's website which is easy to use. In an online environment, there is no sales person but the customer interacts with the website instead, therefore the virtual interaction will provide necessary cues to increase the initial trust towards the company. Useful and easily understood information on the web sites reduces asymmetric information, processes information behaviour, lifts the degree of online trust (Chen and Barnes, 2007, Koufaris and Hampton-Sosa, 2004). By designing a useful and easy to use website, it obviously shows the commitment of company in the relationship with the customers. Therefore, Kamalruzaman (2007) argues that perceived ease-of-use can build up online trust as well as increase the perceived usefulness of e-commerce. Koufaris and Hampton-Sosa (2004) also describe websites that are easy-to-use and useful may lead to increase trust from new customers towards the company.

The studies from Chen and Barnes (2007) and Koufaris and Hampton-Sosa (2004) have suggested that the perceived usefulness of a web site is an antecedent to online trust. However, Gefen et al., (2003) and Erikson et al., (2004) have found that perceived usefulness of a website is not an antecedent of trust. Reicheld and Schefter (cited in Gefen, et al., 2003) state that when the e-vendor is viewed as trustworthy, only then will customers be willing to invest into using the e-vendor's website. Besides, perceived ease of use of a web site is also one of the key elements in influencing online trust. Studies in the past suggest the perceived ease of use a web site has a positive relationship in building online trust towards the company (Gefen et al., 2003; Kamarulzaman, 2007; Koufaris and Hampton-Sosa, 2003). However, Chen and Barnes (2007) argue that the perceived ease of use does not have a significant effect towards building trust. In the online internet banking industry, Erikson et al. (2004) assert that trust is an antecedent to the ease of use. In conclusion, there is no conclusive arguments in related to the relationship between perceived technology (ie. perceived ease of use and perceived usefulness) and online trust in the extant literature. These contradicting arguments between the scholars have prompted the researcher to develop a hypothesis to test the relationship between the perceived technology and online trust (H3) in this research.

Ha and Stoel (2008) suggested that perceived technology is a major determinant in determining online purchase intention. Gefen et al. (2003) also argue that the perceived technology was found to have a direct impact on online purchase intention. According to Gefen et al. (2003), the more useful and easy to use the website, the more customers will choose to use it (online purchase). On the other hand, the studies from Chen and Barnes (2007) and Gefen et al. (2003) also suggest that online purchase intention is influenced by perceived technology, mediated by online trust. Kamarulzaman (2007) stated that the simplicity of the web site design will help to 
motivate the adoption of using the website and increase the intention to use the service (online purchase intention). Therefore, a hypothesized positive relationship between perceived technology and online purchase intention (H4) will be tested in this study. In addition, a hypothesized positive relationship between perceived technology and online purchase intention, mediated by online trust (H5) will be tested in this research.

\subsection{Hypotheses}

From the discussion above, this has lead to the development of the following hypotheses. The five hypotheses are as follows:

H1: There is a positive relationship between online trust and online purchase intention.

$\mathrm{H} 2$ : There is a positive relationship between perceived risk and online trust.

H3: There is a positive relationship between perceived technology and online trust.

H4: There is a positive relationship between perceived technology and online purchase intention.

H5: Perceived technology is positively related to online purchase intention, mediated by online trust.

\section{Research Method}

\subsection{Research Design}

The research design methods being used in this research is quantitative research. Besides, this research involved mainly structured questions which has predetermined and needs a large number of respondents to be involved. Positivistic study was chosen because it has clear specific problem, hypotheses to be tested and detailed information needed.

\subsection{Questionnaire Design}

There are three parts in the design of the questionnaire. The first part asked the respondents about their personal online purchase experience in the past six months. The second part detailed the independent, mediating and dependent variables that would be tested in the survey. And the last part deals with the respondent's demographic question. In measuring the constructs, multi-item scales were used in the questionnaire with adoption from different sources of the existing literature.

The measurement for online purchase intention (three items), trust (nine items) and perceived risk (ten items) were adopted from Chen and Barnes (2007), where else the measurement for perceived technology (eight items) was adopted from Koufaris and Hampton-Sosa (2004). All the items are measured by using a 5-point Likert scale, in which likert scale is ranging from 'strong disagree' to 'strongly agree'.

\subsection{Sampling}

The target population covered all the current full time undergraduate information technology students from a private university in Kuala Lumpur. This target market was selected due to its behavioural characteristics that are more prone to engage in online purchase activities. Only those students who had been involved in the online transaction in the past six months will be invited to participate in the survey.

\subsection{Administration of Survey}

The researchers used self-administered survey method to collect data. Questionnaires were distributed based on the convenience sampling method and conducted in the lecture hall. Questionnaires were given to them with a request to fill in on-the-spot. However, there is a group of respondents that has taken the questionnaire and left without returning it. Thus, there were only 200 sets of questionnaire were collected from a total of 250 distributed. All questionnaire collected were usable with a response rate of $80 \%$.

\subsection{Data Analysis}

The model was testing using the structural equation (SEM) procedure. The central point in analyzing structural models is the extent to which the hypothesized model "fit" or adequately describes the sample data (Hair, Anderson, Tatham \& Black, 2006; Schermelleh-Engel, Moosbrugger \& Müller, 2003). A model fit can be evaluated by examining several goodness of fit indices comprising of $\chi^{2}, \chi^{2} / \mathrm{df}$, GFI, TLI, CFI, and RMSEA as recommended by Malhotra (2010), Hair et al. (2006), Sivo, Fan, Witta and Willse (2006) and Hoe (2008). The cut-off values of these fits are shown in Table 2. Beside, the fit statistics, of particular interest is the path significance indicated by the standardized regression estimate $(\beta)$ that assesses the effect of one variable on another (Chinda \& Mohamed, 2008; Hershberger, Marcoulides \& Parramore, 2003). The significance level was set at $\mathrm{p}<0.05$. Prior to testing the model, the psychometric properties and the goodness of fit of the constructs studied were undertaken. The AMOS software version 18 was employed to analyze the data. 


\section{Research Results}

\subsection{Respondents' Demographic Profile and Online Purchasing Behaviour}

Based on the survey, male respondents represented 45.5 percent of the total respondents while female respondents 54.5 percent. In the case of age distribution, the majority of the respondents were between the ages of 22 to 23 (52 percent) and 18 to 19 (37.5 percent). In terms of ethnic composition, the respondents were mainly Chinese ( 97.5 percent), followed by Indian ( 2 percent), and Malay ( 0.5 percent). In terms of product purchase category, most of the respondents purchase flight tickets via online ( 49.5 percent), followed by clothing (13.5 percent) and electronic gadgets (105 percent). For the online purchase frequency analysis, most of the respondents make online purchases at least once in six months (38.5 percent) and the second highest purchase frequency is at least once in three months (26 percent). For search engine used, majority of the respondents use Google's search engine ( 85.5 percent) when searching the web to make purchases. The second most used search engine is Yahoo (8.5 percent). In terms of money spent per online transaction, most respondents spent RM250 and below ( 55 percent), followed by the RM251 to RM500 (30.5 percent) and RM501 to RM750 (9 percent).

\subsection{Measurement Model (Reliability and Validity)}

This study used the confirmatory factor analysis (CFA) to validate and confirm the dimensionality of the independent, mediating and dependent variables (see Figure 1 and Table 1). Fifteen items (four from perceived technology -- PT; seven from perceived risks -- PR; and four from online trust) were dropped due to weak representation of the data.

The measurement model yielded a good model fit of $\chi^{2}=150.86, \mathrm{p}<0.001, \chi^{2} / \mathrm{df}=1.8, \mathrm{GFI}=0.907$, TLI $=$ 0.919 , CFI $=0.935$, and RMSEA $=0.063$. The Cronbach's alpha values for all the variables were above 0.70 signifying the reliability of the data. The factor loadings provide evidence of convergent validity as described by Anderson and Gerbing (1998) and Anderson (1987), with the threshold value of $>0.30$ (Petrides \& Furnham, 2000). As shown in Table 1, all of the items loadings were significant and well above the acceptable cut-off-point, indicating the convergent validity of the study variables.

\subsection{Hypotheses Testing}

In order to test the hypotheses, the SEM procedure was utilized (see Figure 2). The model yielded a good model fit of $\chi^{2}=151.18, \mathrm{p}<0.001, \chi^{2} / \mathrm{df}=1.78, \mathrm{GFI}=0.907$, TLI $=0.921$, CFI $=0.936$, and RMSEA $=0.063$. All hypotheses were supported. In hypotheses $2(\mathrm{H} 2)$ and $3(\mathrm{H} 3)$, perceived risk $(\beta=0.6, \mathrm{p}<0.001)$ and perceived technology $(\beta=0.23, \mathrm{p}<0.011)$ were significantly and positively related to online trust. In hypothesis $4(\mathrm{H} 4)$, the results of the analysis indicated that the relationship between perceived technology and online purchase intention was statistically significant $(\beta=0.2, p=0.05)$. Even though its magnitude was only 0.2 , the relationship was significance and positive. The outcome of the relationship between trust and online purchase intention (H1) was statistically significant $(\beta=0.38, \mathrm{p}<0.001)$. The significance of the above statistics indicated that hypothesis 5 (H5) was positively supported.

\section{Conclusion}

\subsection{Theoretical and Managerial Contributions of the Research Findings}

There is a significant theoretical and methodological implication in this research. Based on the existing literature, there is no conclusive argument for the relationship between perceived technology (i.e. perceived ease of use and perceived usefulness) and online trust (Koufaris and Hampton-Sosa, 2004; Erikson et al., 2004; Kamarulzaman, 2007; Chen and Barnes, 2007). This research finding concludes that there is a positive relationship between perceived technology and online trust. In other words, the finding of this study supports the argument from Koufaris and Hampton-Sosa (2004). The study of Koufaris and Hampton-Sosa (2004) describes websites that are easy-to-use and useful (i.e., both important components of perceived technology) may lead to increase trust from new customers towards the company. In addition, based on the confirmatory factor analysis, 15 items that measure the constructs (four items for online trust, seven items for perceived risk and four for perceived technology) have been dropped due to weak representation of the data. The remaining items for the constructs have been tested and proved in fulfilling reliability and validity. In conclusion, this research finding has added some theoretical and methodological contributions in the literature.

In terms of managerial implication, the findings do provide some insights and feedback for the e-commerce operators in drafting various managerial strategies on how to increase the shoppers online purchase intention. Operators must create different strategies on how to increase the perceived technology (in term of ease of use and usefulness of the website); minimizing perceived risk (enhancing privacy and protection of the data given, such as strengthening the protection of security code to access credit card information), increase online trust 
(maintaining the level of honesty, keeping promise and ensuring quality, such as providing the superb customer services to alert the inbound and outbound logistics delivery services information to the customer) for the purpose of increasing the likelihood of shopper online purchase intention.

\subsection{Limitations of Research}

Although the research findings provide some new insights to researchers, these findings should be viewed in light of some limitations. The study is based on cross-sectional data that is only able to reveal the net effect of predictor variable towards a particular criterion variable at a specific point in time (Cavana, et. al., 2001). Due to the inherent limitation of cross-sectional study, the research findings are not able to "explain why the observed patterns are there" (Easterby-Smith, Thorpe and Lowe, 2003, p.45). In other words, this research is not able to describe satisfactorily the observed changes in pattern and the causality of the shopper online purchase intention. In addition, the restriction of the boundary set in selecting the full time undergraduate information technology students from a private university in Kuala Lumpur as the sample means that the findings cannot be generalized across all different age groups of shoppers who engage in online transaction activities in the country. Finally, in relation to SEM, the model in this study is only one of many that could result in acceptable goodness of fit. To get the best model, further analysis could be made.

\subsection{Recommendations for Further Research}

Due to the limitations of this research, two recommendations are suggested for the purpose of enhancing the study of the shopper online purchase intention. Since cross-sectional study may not be able to capture the observed changes in patterns and the causality of the online purchase intention (Easterby-Smith, et. al., 2003), longitudinal study is recommended in the future research in order to help researchers in identifying the cause and effect relationships among the various constructs (Cavana, et. al., 2001). Besides, it is also suggested to broaden the research setting by incorporating different age groups of customers and drawing more respondents from different regions in the country. This may enhance the validity and generalization of the research finding. Since the model in this study is only one of many that could result in acceptable goodness of fit, it is suggested to use competing model strategies to find a more parsimonious model (Hair, et al., 2006).

\section{References}

Anderson, J.C. (1987). An approach for confirmatory measurement and structural equation modeling of organizational properties. Management Science, 33(4), 525-541.

Anderson, J.C., \& Gerbing, D.W. (1988). Structural equation modeling in practice: A review and recommended two-step approach. Psychological Bulletin, 103(3), 411-423.

Balasubramanian, S., Konana, P., \& Meron, N. M. (2003). Customer satisfaction in virtual environment: A study of online investing. Management Science, 49(7), 871-889.

Bart, Y., Shankar, V., Sultan, F., \& Urban, G. L. (2005). Are the drivers and role of online trust same for all web sites and consumers? A large-scale exploratory empirical study. Journal of Marketing, 69, 133-152.

Cavana, R.Y., Delahaye, B.L., and Sekaran, H. (2001). Applied business research: Qualitative and quantitative methods. Queensland: John Wiley \& Sons.

Chen, Y., \& Barnes, S. (2007). Initial trust and online buyer behavior. Industrial Management \& Data Systems, 107(1), 21-36.

Chinda, T., \& Mohamed, S. (2008). Structural equation model of construction safety culture. Engineering Construction and Architectural Management, 15(2), 114-131.

Chua, A. P. H., Khatibi, A., \& Hish, I. (2006). E-commerce: A study on online shopping in Malaysia. Journal of Social Science, 13(3), 231-242.

Culnan, M. J., \& Armstrong, P. K. (1999). Information privacy concerns, procedural fairness, and impersonal trust: an empirical investigation. Organization Science, 10(1), 104-115.

Dann, S., \& Dann, S. (2001). Strategic internet marketing. Australia: John Wiley \& Sons.

Davis, F. D. (1989). Perceived usefulness, perceived ease of use, and user acceptance of information technology. MIS Quarterly, 319-340.

Doll, W. J., Hendrickson, A., \& Deng, X. (1998). Using Davis's perceived usefulness and ease-of-use instruments for decision making: A confirmatory and multigroup invariance analysis. Decision Sciences, 29(4), 839-869. 
Easterby-Smith, M., Thorne, R., and Lowe, A. (2003). Management research: An introduction, (2nd ed.), California: SAGE Publication.

Erikson, K., Kerem, K., \& Nilsson, D. (2004). Customer acceptance of internet banking in Estonia. International Journal of Bank Marketing, 23(2), 200-216.

Flavian, C., \& Guinaliu, M. (2006). Consumer trust, perceived security and privacy policy: Three basic elements of loyalty to a website. Industrial Management Science, 28, 725-737.

Gefen, D. (2000). E-commerce: The role of familiarity and trust. International Journal of Management Science, 28, 725-737.

Gefen, D. (2002a). Nurturing clients' trust to encourage engagement success during the customization of ERP systems. Omega, 30(4), 287-299.

Gefen, D. (2002b). Reflections on the dimensions of trust and trustworthiness among online consumers. $A C M$ SIGMIS Database, 33(3), 38-53.

Gefen, D., \& Pavlou, P. A. (2006). An inverted-U theory of trust: The moderating role of perceived regulatory effectiveness of online marketplaces. Twenty Seventh International Conference on Information System, Milwaukee.

Gefen, D., \& Straub, D. W. (2004). Consumer trust in B2C e-commerce and the importance of social presence: experiments in e-products and e-services. Omega, 32, 407-424.

Gefen, D., Karahanna, E., \& Straub, D. W. (2003). Trust and TAM in online shopping: An integrated model. MIS Quarterly, 27(1), 51-90.

Goodwin, C. (1991). Privacy: Recognition of a consumer right. Journal of Public Policy \& Marketing, 10(1), 149-166.

Grabner-Krauter, S., \& Kaluscha, E. A. (2003). Empirical research in on-line trust: A review and critical assessment. International Journal of Human-Computer Studies, 58, 783-812.

Ha, S., \& Stoel, L. (2008). Consumer e-shopping acceptance: Antecedents in a technology acceptance model. Journal of Business Research, J Bus Res (2008), doi:10.1016/j.jbusres.2008.06.016, http://dx.doi.org/10.1016/j.jbusres.2008.06.016

Hair, J.F. Jr., Anderson, R.E., Tatham, R.L., \& Black, W.C. (2006). Multivariate Data Analysis (6th ed.). New Jersey: Prentice-Hall.

Hedelin, L., \& Allwood, C. (2002). IT and strategic decision making. Industrial Management \& Data Systems, 102(3), 125-139.

Henderson, R., \& Divett, M. J. (2003). Perceived usefulness, ease of use and electronic supermarket use. International Journal of Human-Computer Studies, 59, 383-395.

Hershberger, S.L., Marcoulides, G.A., \& Parramore, M.M. (2003). Structural equation modeling: an introduction. In B.H. Pugesek, A. Tomer \& A. von Eye (Eds.), Structural equation modeling: Applications in ecological and evolutionary biology. Cambridge: Cambridge University Press, pp. 3-41.

Hoe, S.L. (2008). Issues and procedures in adopting structural equation modeling technique. Journal of Applied Quantitative Methods, 3(1), 76-83.

Hosmer, L. T. (1995). Trust: the connecting link between organizational theory and philosophical ethics. Academy of Management Review, 20(2), 379-403.

Jarvenpaa, S. L., \& Tractinsky, N. (1999). Consumer trust in an internet store: A cross-cultural validation. Journal of Computer Mediated Communication, 5(2), 1-35.

Kamarulzaman, Y. (2007). Adoption of travel e-shopping in the UK. International Journal of Retail \& Distribution Management, 35(9), 703-719.

Kaur, K. (2005). Consumer protection in e-commerce in Malaysia: An overview. [Online] Available: http://www.une.edu.au/asiacenter/KKaur.pdf (February 02, 2009)

Kim, D. J., Ferrin, D. L., \& Rao, H. R. (2007). A trust-based consumer decision-making model in electronic commerce: The role of trust, perceived risk, and their antecedents. Decision Support System, 44, 544-564.

Koufaris, M., \& Hampton-Sosa, W. (2004). The development of initial trust in an online company by new customers. Information \& Management, 41, 377-397. 
Lee, H., Fiore, A. M., \& Kim, J. (2006). The role of the Technology Acceptance Model in explaining effects of image interactivity technology on consumer responses. International Journal of Retail \& Management, 34(8), 621-644.

Lee, M. K. O., \& Turban, E. (2001). A trust model for consumer internet shopping. International Journal of Electronic Commerce, 4(1), 75-91.

Maholtra, N. K., \& Peterson, M. (2006). Basic marketing research: A decision-making approach (2nd ed.). New Jersey: Pearson Education, Inc.

Malaysia Communication and Multimedia Commission (MCMC). (2008). 2003 Q3communications \& multimedia - selected facts and figures. [Online] Available: http://www.skmm.gov.my/facts_figures/stats/pdf/Quarter3_2008.pdf (February 03, 2009)

Malaysia Prime Minister Department (n.d.), Ninth Malaysia Plan 2006-2010: Official website of Economic Planning Unit - Malaysia Prime Minister Department (n.d.). [Online] Available: http://www.epu.jpm.my/rm9/english/Chapter9.pdf (February 02, 2009)

Malhotra, N.K. (2010). Marketing research: An applied orientation (6th ed.). New Jersey: Pearson.

Mayer, R., Davis, J., \& Shoorman, F. (1995). An integrative model of organizational trust. Academy of Management Review, 20(3), 709-734.

McKechnie, S., Winklhofer, H., \& Ennew, C. (2006). Applying the technology acceptance model to the online retailing of financial services. International Journal of Retail \& Distribution Management, 34 (4/5), 388-410.

McKnight, D. H., \& Chervany, N. L. (2001). What trust means in e-commerce customer relationships: An interdisciplinary conceptual typology. International Journal of Electronic Commerce, 6(2), 35-39.

Monsuwe, T. P., Delleart, B. G. C., \& Ruyter, K. (2004). What drives consumers to shop online? A literature review. International Journal of Service Industry Management, 15(1), 102-121.

Moorman, C., Zaltman, G., \& Deshpande, R. (1992). Relationship between providers and users of marketing research: the dynamics of trust within and between organizations. Journal of Marketing Research, 29(3), 314-329.

Morgan, R. M., \& Hunt, S. D. (1994). The commitment-trust theory of relationship marketing. Journal of Marketing, 58, 20-38.

Murkherjee, A., \& Nath, P. (2007). Role of electronic trust in online retailing: A re-examination of the commitment-trust theory. European Journal of Marketing, 41(9/10), 1173-1202.

Murphy, P. E., \& Enis, B. M. (1986). Classifying products strategically. Journal of Marketing, 50, 24-42.

Park, C., \& Jun, J. K. (2003). A cross-cultural comparison of internet buying behavior: Effects of internet usage, perceived risks, and innovativeness. International Marketing Review, 20(5), 265-335.

Pavlou, P. A. (2003). Consumer acceptance of electronic commerce: Integrating trust and risk with the technology acceptance model. International Journal of Electronic Commerce, 7(3), 197-226.

Peter, J. P., \& Ryan, M. J. (1976). An investigation of perceived risk at the brand level. Journal of Marketing Research, XIII, 184-188.

Petrides, K.V., \& Furnham, A. (2000). On the dimentional structure of emotional intelligence. Personality and Individual Difference, 29, 313-320.

Rempel, J. K., Holmes, J. G., \& Zanna, M. P. (1985). Trust in close relationships. Journal of Personality and Social Psychology, 49(1), 95-112.

Rousseau, D., Sitkin, S., Burt, R., \& Camerer, R. (1998). Not so different after all: A cross discipline view of trust. Academy of Management Review, 23(3), 393-404.

Schermelleh-Engel, K., Moosbrugger, H., \& Müller, H. (2003). Evaluating the fit of structural equation models: Tests of significance and descriptive goodness-of-fit measures. Methods of Psychological Research Online, 8(2), 23-74. [Online] Available: http://user.uni-frankfurt.de/ kscherm/schermelleh/mpr_Schermelleh.pdf. (February 17, 2010)

Shelly, G. B., Cashman, T. J., \& Vermaat, M. E. (2007). Discovering computers: A gateway to information. United States: Thomson Course Technology. 
Sivo, S.A., Fan, X., Witta, E.L., \& Willse, J.T. (2006). The search for "optimal" cutoff properties: fit index criteria in structural equation modeling. The Journal of Experimental Education, 74(3), 267-288.

So, M., \& Sculli, D. (2002). The role of trust, quality, value and risk in conducting e-business. Industrial Management \& Data Systems, 102(9), 503-512.

Taylor, J. W. (1974). The role of risk in consumer behavior. Journal of Marketing, 8, 54-60.

Urban, G. L., Sultan, F., \& Qualls, W. J. (2000). Placing trust at the center of your internet strategy. Sloan Management Review, 42(1), 39-48.

Wang, S. L. (2003). Customer testimonials and new clips as contextual cues in the consumer cognitive processing of online shopping: How do they build trust and then increase purchase intention? Journal of Promotion Management, 9(1/2), 145-162.

Warrington, T. B., Abgrab, N. J., \& Caldwell, M. (2000). Building trust to develop competitive advantage in E-business relationships. Competitiveness Review, 10(2), 160-168.

Yoon, S. J. (2002). The antecedents and consequences of trust in online-purchase decisions. Journal of Interactive Marketing, 16(2), 47-63.

Zikmund, W., \& Scott, J. (1973). A Multivariate analysis of perceived risk, self confidence and information sources, in S. Ward, P. Wright (Eds.), Advances in Consumer Research, 1, Association for Consumer Research, Urbana, IL, 406-416.

Zwass, V. (1998). Structure and macro-level impacts of electronic commerce: from technological infrastructure to electronic marketplace, Kendall, K. (Ed.), Emerging Information Technologies. CA: Sage, Thousand Oaks.

Table 1. Factor Loadings and Cronbach's Alpha Values for the Study Variables

\begin{tabular}{|c|c|c|c|}
\hline & Variables & $\begin{array}{c}\text { Factor } \\
\text { Loading }(\lambda)\end{array}$ & $\begin{array}{l}\text { Cronbach } \\
\text { Alpha }(\alpha)\end{array}$ \\
\hline \multirow[t]{4}{*}{1} & Online Purchase Intention & & 0.81 \\
\hline & $\begin{array}{l}\text { It is likely that I will perform a business transaction with this } \\
\text { web retailer in the near future. }\end{array}$ & 0.65 & \\
\hline & Given the chance, I intend to use this retailer's website. & 0.90 & \\
\hline & $\begin{array}{l}\text { Given the chance, I predict that I shall use this retailer's website } \\
\text { in the future. }\end{array}$ & 0.79 & \\
\hline \multirow[t]{5}{*}{2} & Perceived Technology & & 0.84 \\
\hline & Using this website can improve my shopping performance. & 0.79 & \\
\hline & Using this website can increase my shopping productivity. & 0.75 & \\
\hline & Using this website can increase my shopping effectiveness. & 0.80 & \\
\hline & I find using this website is useful. & 0.70 & \\
\hline \multirow[t]{4}{*}{3} & Perceived Risks & & 0.75 \\
\hline & $\begin{array}{l}\text { The personal information that I provide on this website is } \\
\text { secure. }\end{array}$ & 0.79 & \\
\hline & $\begin{array}{l}\text { The monetary information that I provide on this website is well } \\
\text { protected. }\end{array}$ & 0.79 & \\
\hline & $\begin{array}{l}\text { This website will not use unsuitable methods to collect my } \\
\text { personal data. }\end{array}$ & 0.57 & \\
\hline \multirow[t]{6}{*}{4} & Trust & & 0.71 \\
\hline & This website is trustworthy and honest. & 0.56 & \\
\hline & This website wants to keep promises and obligations. & 0.56 & \\
\hline & The information on this website is plentiful and sufficient. & 0.62 & \\
\hline & The infrastructure of this website is dependable. & 0.59 & \\
\hline & The website offers secure personal privacy. & 0.52 & \\
\hline
\end{tabular}


Table 2. Measurement Model Fit Guide

\begin{tabular}{|c|c|c|}
\hline $\begin{array}{c}\text { Statistic } \\
\text { (range) }\end{array}$ & Recommended value & Description \\
\hline$\chi^{2}$ & $\begin{array}{l}\text { Statistical test of significance } \\
\text { provided } \\
\text { The } 0.05 \text { significance level is } \\
\text { recommended as the minimum } \\
\text { accepted, and levels of } 0.1 \text { or } \\
0.2 \text { should be exceeded before } \\
\text { non-significance is confirmed } \\
\text { (Hair et al., 2006) }\end{array}$ & $\begin{array}{l}\text { The chi-square statistics is used to test the } \\
\text { statistical significance of the observed } \\
\text { association in a cross-tabulation and it assists in } \\
\text { determining whether a systematic association } \\
\text { exists between the two variables (Malhotra, } \\
\text { 2010). In relation to SEM, Malhotra further } \\
\text { defined the chi-square test is used to provide a } \\
\text { statistical test of the difference in the covariance } \\
\text { matrices such that } \chi^{2}=(\mathrm{n}-1) \text { (observed sample } \\
\text { covariance matrix - estimated covariance } \\
\text { matrix) where } \mathrm{n} \text { is the sample size. A large } \\
\text { value of chi-square relative to the degrees of } \\
\text { freedom signifies that the observed and } \\
\text { estimated matrices differ (Hair et al., 2006). } \\
\text { They further described that low chi-square } \\
\text { values, which result in significant levels greater } \\
\text { than 0.05 or } 0.01 \text { indicated the actual and } \\
\text { predicted input matrices are not statistically } \\
\text { different. }\end{array}$ \\
\hline $\begin{array}{c}\text { GFI } \\
(0-1)\end{array}$ & $\begin{array}{ll}- & >0.9 \text { (good fit) } \\
& \text { (Schermelleh-Engel, } \\
& \text { Moosbrugger \& Müller, 2003) } \\
\text { - } & \text { Higher values indicate better fit } \\
& \text { (Hair et al., 2006) }\end{array}$ & $\begin{array}{l}\text { The goodness-of-fit index (GFI) is a } \\
\text { non-statistical measure that represents the } \\
\text { overall degree of fit (the squared residuals from } \\
\text { prediction compared with the actual data), but is } \\
\text { not adjusted for the degrees of freedom (Hair et } \\
\text { al., 2006). }\end{array}$ \\
\hline $\begin{array}{c}\text { RMSEA } \\
\text { (N/A) }\end{array}$ & $\begin{array}{ll}-\quad & <0.05 \text { (good fit) } \\
& \text { (Schermelleh-Engel, } \\
& \text { Moosbrugger \& Müller, 2003) } \\
& <0.08 \text { (reasonable fit) (Hair et } \\
& \text { al., 2006; Hoe, 2008) }\end{array}$ & $\begin{array}{l}\text { The root mean square error of approximation } \\
\text { (RMSEA) is a measure to correct for the } \\
\text { tendency of the chi-square statistic to reject any } \\
\text { specified model with a sufficiently large sample } \\
\text { (Hair et al., 2006). }\end{array}$ \\
\hline $\begin{array}{l}\text { TLI } \\
(0-1)\end{array}$ & $\begin{array}{l}-\quad>0.9 \text { (good fit) (Hoe, 2008; Hair } \\
\quad \text { et al., 2006) } \\
-\quad>0.97 \text { (Schermelleh-Engel, } \\
\\
\text { Moosbrugger \& Müller, 2003) }\end{array}$ & $\begin{array}{l}\text { The Tucker-Lewis index (TLI) measures of } \\
\text { parsimony into a comparative index between the } \\
\text { estimated and null models. This measure can } \\
\text { also be used for comparing between alternative } \\
\text { models by substituting the alternative model for } \\
\text { the null model (Hair et al., 2006). }\end{array}$ \\
\hline $\begin{array}{l}\text { CFI } \\
(0-1)\end{array}$ & 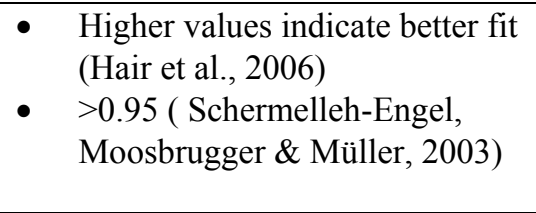 & $\begin{array}{l}\text { The comparative fit index (CFI) measures } \\
\text { comparisons between the estimated model and a } \\
\text { null or independence model. The CFI has been } \\
\text { found to be more appropriate in a model } \\
\text { development strategy (Hair et al., 2006). }\end{array}$ \\
\hline $\begin{array}{l}\text { Normed } \\
\text { Chi-square } \\
\text { (N/A) }\end{array}$ & $<3.00($ Hoe, 2008$)$ & $\begin{array}{l}\text { The likelihood-ratio chi-square statistic with a } \\
\text { large value of chi-square relative to the degrees } \\
\text { of freedom signifies that the observed and } \\
\text { estimated matrices differ (Hair et al., 2006). }\end{array}$ \\
\hline
\end{tabular}




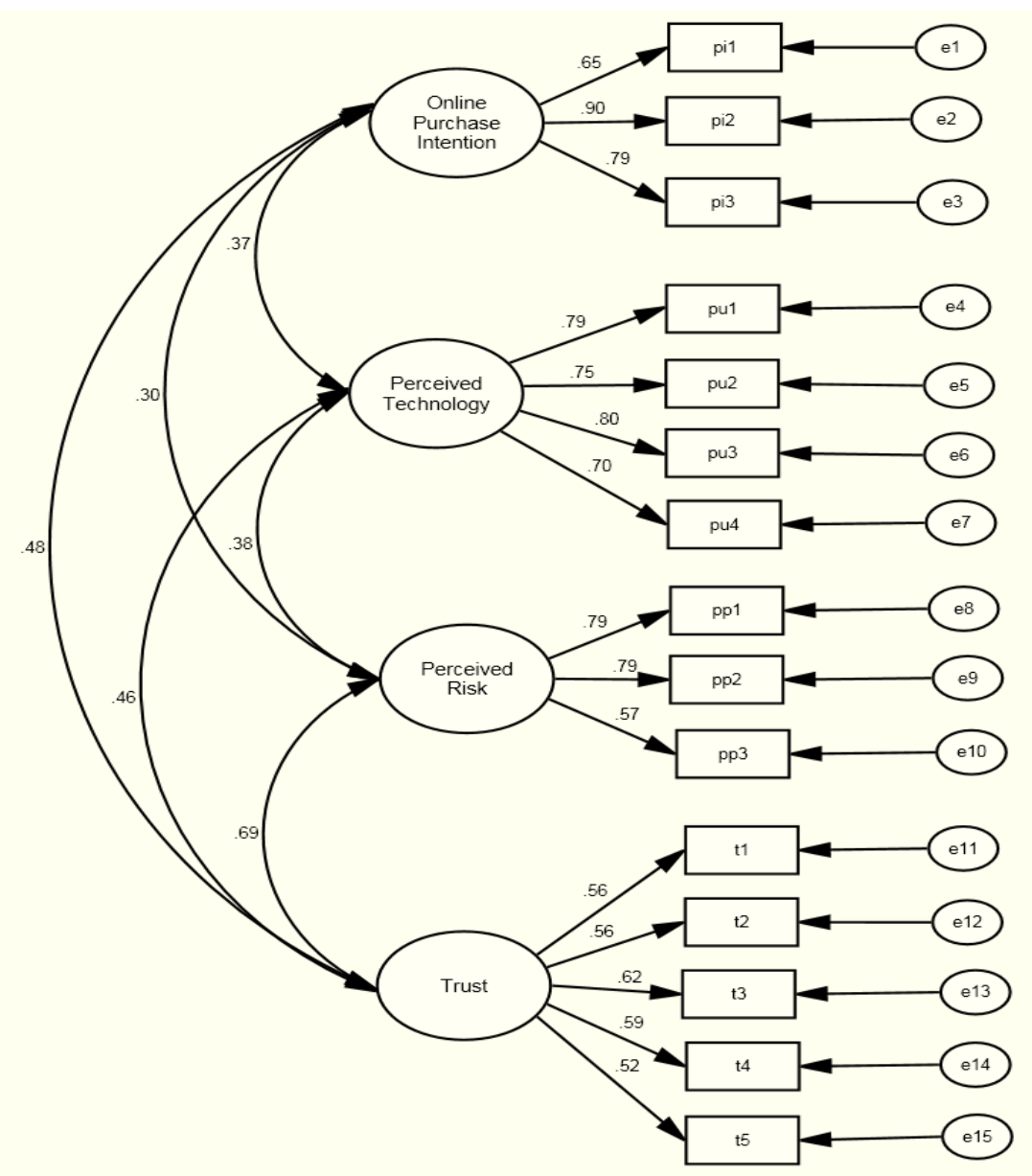

Figure 1. Measurement Model

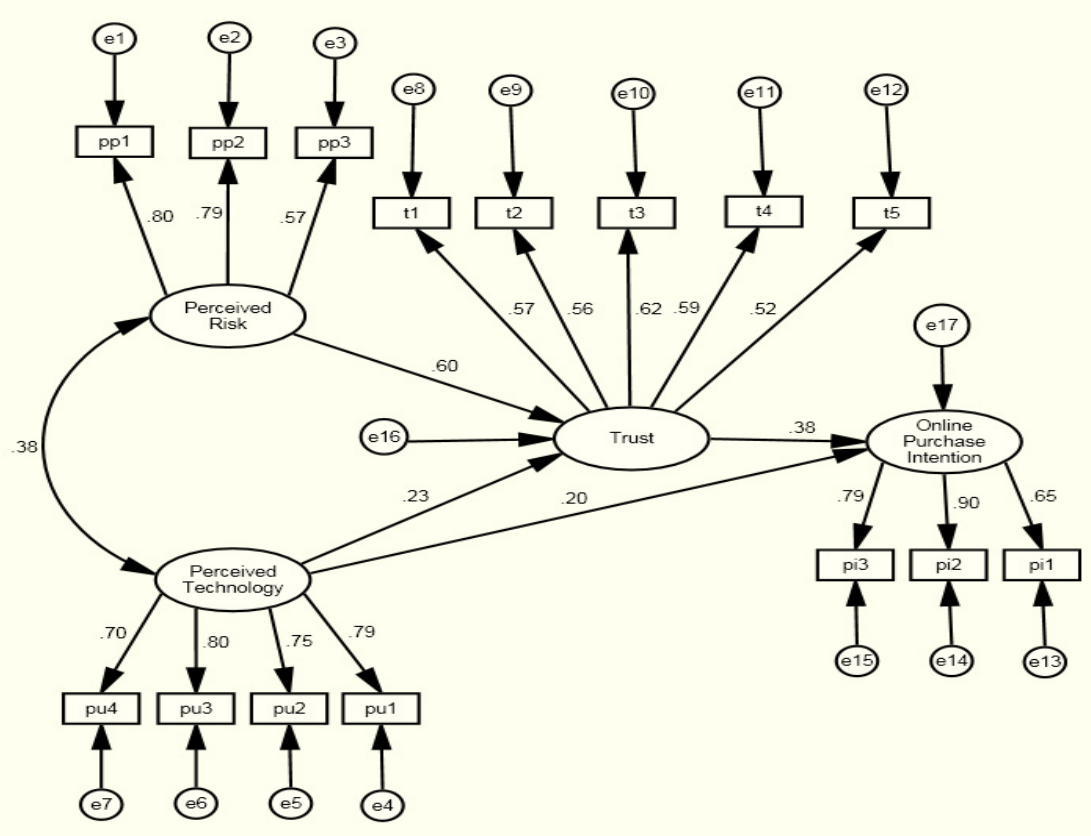

Figure 2. Estimated Model for Structural Equation Modeling 


\section{AMOS Output for Measurement Model}

Estimates (Group number 1 - Default model)

Scalar Estimates (Group number 1 - Default model)

Maximum Likelihood Estimates

Regression Weights: (Group number 1 - Default model)

\begin{tabular}{|c|c|c|c|c|c|c|}
\hline & & & Estimate & S.E. & C.R. & $\mathrm{P}$ \\
\hline Trust & $<---$ & Perceived_Risk & .414 & .081 & 5.128 & $* * *$ \\
\hline Trust & $<---$ & Perceived_Technology & .143 & .057 & 2.529 & .011 \\
\hline Online_Purchase_Intention & $<---$ & Trust & .431 & .126 & 3.414 & $* * *$ \\
\hline Online_Purchase_Intention & $<---$ & Perceived_Technology & .142 & .067 & 2.131 & .033 \\
\hline q6pi & $<---$ & Online_Purchase_Intention & 1.000 & & & \\
\hline q7pi & $<---$ & Online_Purchase_Intention & 1.398 & .153 & 9.134 & $* * *$ \\
\hline q8pi & $<---$ & Online_Purchase_Intention & 1.200 & .132 & 9.060 & $* * *$ \\
\hline q32pu & $<---$ & Perceived_Technology & 1.000 & & & \\
\hline q33pu & $<---$ & Perceived_Technology & .945 & .091 & 10.395 & $* * *$ \\
\hline $\mathrm{q} 34 \mathrm{pu}$ & $<---$ & Perceived_Technology & 1.015 & .092 & 11.064 & $* * *$ \\
\hline $\mathrm{q} 35 \mathrm{pu}$ & $<---$ & Perceived_Technology & .767 & .079 & 9.661 & $* * *$ \\
\hline q23pp & $<---$ & Perceived_Risk & 1.000 & & & \\
\hline $\mathrm{q} 24 \mathrm{pp}$ & $<---$ & Perceived_Risk & .909 & .098 & 9.272 & $* * *$ \\
\hline $\mathrm{q} 25 \mathrm{pp}$ & $<---$ & Perceived_Risk & .665 & .091 & 7.278 & $* * *$ \\
\hline$q 9 t$ & $<---$ & Trust & 1.000 & & & \\
\hline $\mathrm{q} 10 \mathrm{t}$ & $<---$ & Trust & .891 & .155 & 5.734 & $* * *$ \\
\hline $\mathrm{q} 11 \mathrm{t}$ & $<---$ & Trust & 1.167 & .191 & 6.098 & $* * *$ \\
\hline $\mathrm{q} 12 \mathrm{t}$ & $<---$ & Trust & .980 & .166 & 5.899 & $* * *$ \\
\hline$q 13 t$ & $<---$ & Trust & .883 & .163 & 5.424 & $* * *$ \\
\hline
\end{tabular}

Standardized Regression Weights: (Group number 1 - Default model)

\begin{tabular}{lllr}
\hline & & & Estimate \\
\hline Trust & $<---$ & Perceived_Risk & .599 \\
Trust & $<---$ & Perceived_Technology & .228 \\
Online_Purchase_Intention & $<---$ & Trust & .376 \\
Online_Purchase_Intention & $<---$ & Perceived_Technology & .197 \\
q6pi & $<---$ & Online_Purchase_Intention & .646 \\
q7pi & $<---$ & Online_Purchase_Intention & .898 \\
q8pi & $<---$ & Online_Purchase_Intention & .794 \\
q32pu & $<---$ & Perceived_Technology & .785 \\
q33pu & $<---$ & Perceived_Technology & .752 \\
q34pu & $<---$ & Perceived_Technology & .804 \\
q35pu & $<---$ & Perceived_Technology & .701 \\
q23pp & $<---$ & Perceived_Risk & .796 \\
q24pp & $<---$ & Perceived_Risk & .789 \\
q25pp & $<---$ & Perceived_Risk & .568 \\
q9t & $<---$ & Trust & .565 \\
q10t & $<---$ & Trust & .562 \\
q11t & $<---$ & Trust & .621 \\
q12t & $<---$ & Trust & .588 \\
q13t & $<---$ & Trust & .518 \\
\hline & & & \\
& & & .79 \\
& & & \\
& & &
\end{tabular}


Covariances: (Group number 1 - Default model)

\begin{tabular}{lrrrrr}
\hline & Estimate & S.E. & C.R. & P & Label \\
\hline Perceived_Technology $<-->$ Perceived_Risk & .143 & .036 & 4.020 & $* * *$ & \\
\hline
\end{tabular}

Correlations: (Group number 1 - Default model)

\begin{tabular}{|c|c|c|c|c|c|c|}
\hline & & & & Est & imate & \\
\hline & Perceived_Technology & $<-->$ & Perceived_Ris & & .38 & \\
\hline Variances: (Group nı & umber 1 - Default model) & & & & & \\
\hline & & Estimate & S.E. & C.R. & $\mathrm{P}$ & Label \\
\hline & Perceived_Technology & .411 & .067 & 6.178 & $* * *$ & \\
\hline & Perceived_Risk & .341 & .058 & 5.872 & $* * *$ & \\
\hline & e21 & .079 & .024 & 3.297 & $* * *$ & \\
\hline & e20 & .160 & .035 & 4.636 & $* * *$ & \\
\hline & e1 & .299 & .034 & 8.767 & $* * *$ & \\
\hline & e2 & .101 & .031 & 3.291 & $* * *$ & \\
\hline & e3 & .179 & .028 & 6.390 & $* * *$ & \\
\hline & e8 & .256 & .036 & 7.159 & $* * *$ & \\
\hline & e9 & .283 & .037 & 7.716 & $* * *$ & \\
\hline & $\mathrm{e} 10$ & .231 & .034 & 6.771 & $* * *$ & \\
\hline & e11 & .250 & .030 & 8.313 & $* * *$ & \\
\hline & $\mathrm{e} 12$ & .197 & .035 & 5.612 & $* * *$ & \\
\hline & e13 & .171 & .030 & 5.777 & $* * *$ & \\
\hline & e14 & .316 & .036 & 8.864 & $* * *$ & \\
\hline & e15 & .346 & .040 & 8.569 & $* * *$ & \\
\hline & e16 & .279 & .032 & 8.591 & $* * *$ & \\
\hline & e17 & .353 & .044 & 8.089 & $* * *$ & \\
\hline & e18 & .295 & .035 & 8.392 & $* * *$ & \\
\hline & $\mathrm{e} 19$ & .345 & .039 & 8.880 & $* * *$ & \\
\hline
\end{tabular}

\section{Model Fit Summary}

CMIN

\begin{tabular}{lrrrrr}
\hline Model & NPAR & CMIN & DF & P & CMIN/DF \\
\hline Default model & 35 & 151.176 & 85 & .000 & 1.779 \\
Saturated model & 120 & .000 & 0 & & \\
Independence model & 15 & 1138.082 & 105 & .000 & 10.839 \\
\hline
\end{tabular}

RMR, GFI

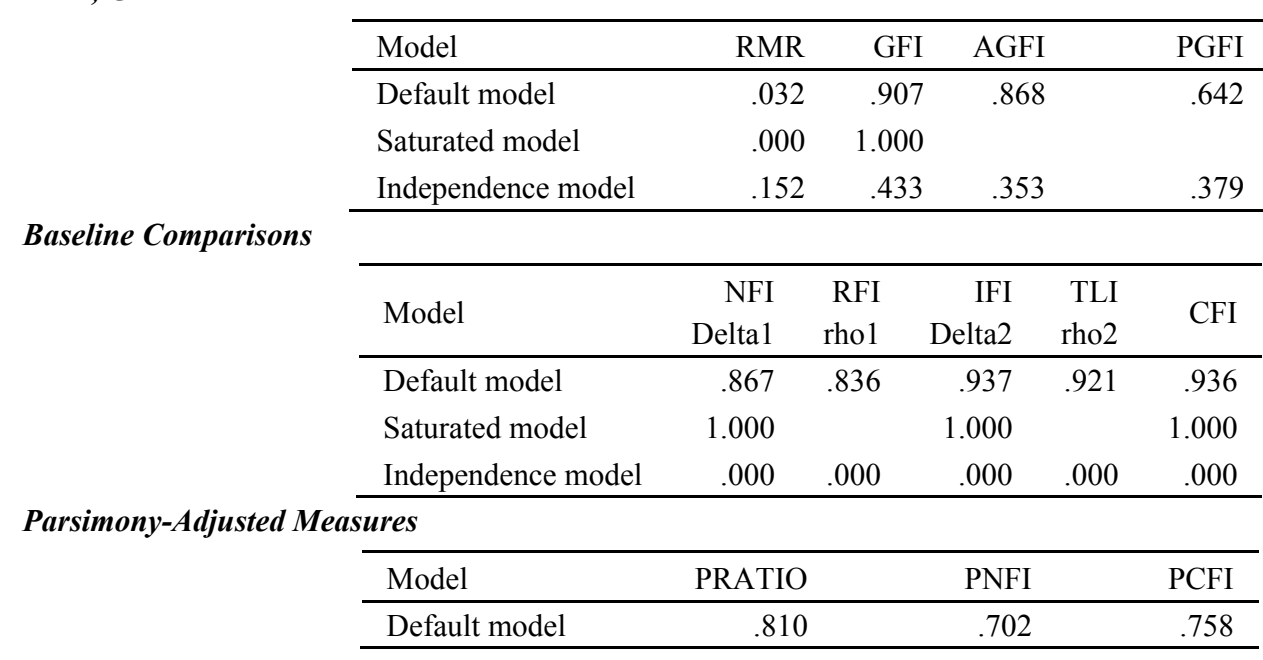


NCP

FMIN

\begin{tabular}{lrrr}
\hline Model & PRATIO & PNFI & PCFI \\
\hline Saturated model & .000 & .000 & .000 \\
Independence model & 1.000 & .000 & .000 \\
\hline
\end{tabular}

\begin{tabular}{lrrr}
\hline Model & NCP & LO 90 & HI 90 \\
\hline Default model & 66.176 & 35.744 & 104.456 \\
Saturated model & .000 & .000 & .000 \\
Independence model & 1033.082 & 928.369 & 1145.227 \\
\hline
\end{tabular}

RMSEA

\begin{tabular}{lrrrr}
\hline Model & FMIN & F0 & LO 90 & HI 90 \\
\hline Default model & .760 & .333 & .180 & .525 \\
Saturated model & .000 & .000 & .000 & .000 \\
Independence model & 5.719 & 5.191 & 4.665 & 5.755 \\
\hline
\end{tabular}

AIC

\begin{tabular}{lrrrr}
\hline Model & RMSEA & LO 90 & HI 90 & PCLOSE \\
\hline Default model & .063 & .046 & .079 & .102 \\
Independence model & .222 & .211 & .234 & .000 \\
\hline
\end{tabular}

\begin{tabular}{lrrrr}
\hline Model & AIC & BCC & BIC & CAIC \\
\hline Default model & 221.176 & 227.296 & 336.617 & 371.617 \\
Saturated model & 240.000 & 260.984 & 635.798 & 755.798 \\
Independence model & 1168.082 & 1170.705 & 1217.557 & 1232.557 \\
\hline
\end{tabular}

ECVI

HOELTER

\begin{tabular}{lrrrr}
\hline Model & ECVI & LO 90 & HI 90 & MECVI \\
\hline Default model & 1.111 & .959 & 1.304 & 1.142 \\
Saturated model & 1.206 & 1.206 & 1.206 & 1.311 \\
Independence model & 5.870 & 5.344 & 6.433 & 5.883 \\
\hline
\end{tabular}

\begin{tabular}{lrr}
\hline \multirow{2}{*}{ Model } & HOELTER & HOELTER \\
& .05 & .01 \\
\hline Default model & 142 & 156 \\
Independence model & 23 & 25 \\
\hline
\end{tabular}

AMOS Output for Estimated Model

Model Fit Summary

CMIN

RMR, GFI

\begin{tabular}{lrrrrr}
\hline Model & NPAR & CMIN & DF & P & CMIN/DF \\
\hline Default model & 36 & 150.856 & 84 & .000 & 1.796 \\
Saturated model & 120 & .000 & 0 & & \\
Independence model & 15 & 1138.082 & 105 & .000 & 10.839 \\
\hline
\end{tabular}

\begin{tabular}{lrrrr}
\hline Model & RMR & GFI & AGFI & PGFI \\
\hline Default model & .032 & .907 & .867 & .635 \\
Saturated model & .000 & 1.000 & & \\
Independence model & .152 & .433 & .353 & .379 \\
\hline
\end{tabular}

Baseline Comparisons

\begin{tabular}{lrrrrr}
\hline \multirow{2}{*}{ Model } & NFI & RFI & IFI & TLI & \\
& Delta1 & rho1 & Delta2 & rho2 & CFI \\
\hline
\end{tabular}




\begin{tabular}{lrrrrr}
\hline Model & $\begin{array}{r}\text { NFI } \\
\text { Delta1 }\end{array}$ & $\begin{array}{r}\text { RFI } \\
\text { rho1 }\end{array}$ & $\begin{array}{r}\text { IFI } \\
\text { Delta2 }\end{array}$ & $\begin{array}{r}\text { TLI } \\
\text { rho2 }\end{array}$ & CFI \\
\hline Default model & .867 & .834 & .937 & .919 & .935 \\
Saturated model & 1.000 & & 1.000 & & 1.000 \\
Independence model & .000 & .000 & .000 & .000 & .000 \\
\hline
\end{tabular}

Parsimony-Adjusted Measures

\begin{tabular}{|c|c|c|c|c|c|}
\hline & \\
\hline & Model & PRATIO & & NFI & PCFI \\
\hline & Default model & .800 & & .694 & .748 \\
\hline & Saturated model & .000 & & .000 & .000 \\
\hline & Independence model & 1.000 & & .000 & .000 \\
\hline \multicolumn{6}{|l|}{$N C P$} \\
\hline & Model & $\mathrm{NCP}$ & \multicolumn{2}{|c|}{ LO 90} & HI 90 \\
\hline & Default model & 66.856 & \multicolumn{2}{|c|}{36.393} & 105.162 \\
\hline & Saturated model & .000 & \multicolumn{2}{|r|}{.000} & .000 \\
\hline & Independence model & 1033.082 & \multicolumn{2}{|c|}{928.369} & 1145.227 \\
\hline \multicolumn{6}{|l|}{ FMIN } \\
\hline & Model & FMIN & F0 & LO 90 & HI 90 \\
\hline & Default model & .758 & .336 & .183 & .528 \\
\hline & Saturated model & .000 & .000 & .000 & .000 \\
\hline & Independence model & 5.719 & 5.191 & 4.665 & 5.755 \\
\hline \multicolumn{6}{|l|}{ RMSEA } \\
\hline & Model & RMSEA & LO 90 & HI 90 & PCLOSE \\
\hline & Default model & .063 & .047 & .079 & .091 \\
\hline & Independence model & .222 & .211 & .234 & .000 \\
\hline \multicolumn{6}{|l|}{$A I C$} \\
\hline & Model & AIC & $\mathrm{BCC}$ & $\mathrm{BIC}$ & CAIC \\
\hline & Default model & 222.856 & 229.151 & 341.596 & 377.596 \\
\hline & Saturated model & 240.000 & 260.984 & 635.798 & 755.798 \\
\hline & Independence model & 1168.082 & 1170.705 & 1217.557 & 1232.557 \\
\hline \multicolumn{6}{|l|}{$E C V I$} \\
\hline & Model & ECVI & LO 90 & HI 90 & MECVI \\
\hline & Default model & 1.120 & .967 & 1.312 & 1.152 \\
\hline & Saturated model & 1.206 & 1.206 & 1.206 & 1.311 \\
\hline & Independence model & 5.870 & 5.344 & 6.433 & 5.883 \\
\hline \multicolumn{6}{|l|}{ HOELTER } \\
\hline & Model & & $\begin{array}{r}\text { HOELTER } \\
.05 \\
\end{array}$ & & $\begin{array}{r}\text { HOELTER } \\
.01 \\
\end{array}$ \\
\hline & Default model & & 141 & & 155 \\
\hline & Independence model & & 23 & & 25 \\
\hline
\end{tabular}

